\title{
Associations of gender and serum total cholesterol with CD4+ T cell count and HIV RNA load in antiretroviral-naïve individuals in Addis Ababa
}

Melaku Adal ${ }^{1,2^{*}}$ D, Rawleigh Howe ${ }^{2+}$, Desta Kassa ${ }^{3+}$, Abraham Aseffa $^{2+}$ and Beyene Petros ${ }^{1+}$

\begin{abstract}
Background: Males are more susceptible than females to infections due to the differences in endocrine-immune interactions. Furthermore, it is reported that lowering cell cholesterol impairs viral replication and infection in vitro. However, the production of oxysterols in vivo by oxidation of cholesterol may result in inhibition of HIV replication. Therefore, this study was designed to determine the associations of gender and serum total cholesterol with CD4+ T cell counts and/or WHO clinical stages, and HIV ribonucleic acid (RNA) load in antiretroviral therapy (ART) naive study population with known sero-positive time of stay in Addis Ababa.

Methods: A cross-sectional study was conducted from February to August 2013 on 594 HIV-1 infected ART-naïve adult study participants in four hospitals Addis Ababa. CD4+ T-cell count, HIV RNA load, hemoglobin and fasting serum total cholesterol were determined. Socio-demographic characteristics, WHO clinical stages, and height and weight were collected from patients' chart and triangulated by structured questionnaire. Pearson chi-square test, Spearman rank correlation and univariate and multivariate linear/logistic regression analyses were carried out to determine associations.

Results: Mean HIV RNA load was found to be lower in women than in men $(p<0.05)$. CD4+ T cell count and serum total cholesterol were found to be significantly correlated with HIV RNA load $(p<0.01)$. Women were at lower risk of having higher HIV RNA load in comparison to men. In addition, having lower concentrations of serum total cholesterol was found to be independent predictor of higher HIV RNA load in comparison to those with higher concentrations of cholesterol in serum $(p<0.05)$. The multivariate binomial logistic regression also showed that the immune status was better in women than men, and in the presence of higher serum total cholesterol $(p<0.05)$.

Conclusion: Gender and serum total cholesterol were found to be associated and independent predictors of HIV RNA load, and CD4+ cell count and/or WHO clinical stages. There is a significant lower HIV RNA load and better CD4+ T cell count in women and those study participants with higher serum total cholesterol.
\end{abstract}

Keywords: Gender, Total cholesterol, ART naïve, HIV RNA load, CD4+ T cell count

\footnotetext{
* Correspondence: melakuadal@gmail.com

${ }^{\dagger}$ Rawleigh Howe, Desta Kassa, Abraham Aseffa and Beyene Petros contributed equally to this work.

${ }^{1}$ Microbial, Cellular and Molecular Biology Department, Addis Ababa

University, Addis Ababa, Ethiopia

${ }^{2}$ Armauer Hansen Research Institute, Addis Ababa, Ethiopia

Full list of author information is available at the end of the article
}

(c) The Author(s). 2018 Open Access This article is distributed under the terms of the Creative Commons Attribution 4.0 International License (http://creativecommons.org/licenses/by/4.0/), which permits unrestricted use, distribution, and reproduction in any medium, provided you give appropriate credit to the original author(s) and the source, provide a link to the Creative Commons license, and indicate if changes were made. The Creative Commons Public Domain Dedication waiver (http://creativecommons.org/publicdomain/zero/1.0/) applies to the data made available in this article, unless otherwise stated. 


\section{Background}

According to the Joint United Nations Program on human immunodeficiency virus (HIV) and Acquired immune deficiency syndrome (AIDS) UNAIDS [1], an estimated 36.9 million people live with HIV globally, out of which about 25.8 million (70\%) are in sub-Saharan Africa. HIV adult prevalence in Ethiopia was estimated at $1.5 \%$, i.e., $1.9 \%$ in females and $1.0 \%$ in males; the urban HIV prevalences was $5.2 \%$ in females and $2.9 \%$ in males; and rural prevalence was $0.8 \%$ in females and $0.5 \%$ in males. In addition, the prevalence of HIV in Addis Ababa was $6.0 \%$ in females and $4.3 \%$ in males [2]. The total estimated number of Ethiopians living with HIV was 793,700 [3], mainly infected by the subtype $C[4,5]$. The World Health Organization (WHO) [6] currently recommends initiation of ART in people living with HIV/AIDS at any CD4+ T cell count regardless of the $\mathrm{WHO}$ clinical stages, giving priority to those with severe or advanced HIV disease (WHO clinical stages III/IV) or a CD4 T cell count $\leq 350$ cells $/ \mathrm{mm}^{3}$.

Total cholesterol could be used as important biomarker since lipids have a role in viral entry, uncoating, replication, protein synthesis, assembly, budding and infectivity [7, 8]. Replication of viruses is dependent upon regulation of the cellular cholesterol balance $[9,10]$ and endocrine-immunity interaction that differ along gender [11-13]. Viruses use membrane microdomains where viral cholesterol-rich region, receptors and/or coreceptors are localized called lipid rafts to infect the target cells $[14,15]$. Nef of HIV inhibits activity of the ATP binding cassette transporter A1 (ABCA1) [16], and impairs cholesterol efflux [17, 18]. Nef also induces genes involved in cholesterol biosynthesis [17] and facilitate cholesterol delivery to lipid rafts [19]. Inhibiting its biosynthesis or depletion of cellular cholesterol by stimulation of cholesterol efflux through activation of ABCA1 suppresses HIV-1 infection and replication in vitro $[20,21]$.

During viral infection in vivo, the innate immune system produces interferons (IFNs) that are involved in up-regulation of interferon-stimulated genes (ISGs). Some of the ISGs are involved in production of oxysterols [22]. Cholesterol-25-hydroxylase (Ch25h) is one of the antiviral ISGs that can convert cholesterol to 25-hydroxycholesterol (25-HC). 25-HC inhibits viral entry by blocking membrane fusion between virus and cell $[23,24]$. In addition, $25-\mathrm{HC}$ controls sterol biosynthesis by feedback inhibition [25], and promotion of down-regulation of the enzymes involved in sterol biosynthesis [26].

Males are more susceptible than females to infections due to the differences in endocrine-immune interactions [11]. In support to this, studies showed that plasma HIV-1 RNA levels in women are lower than in men [27, 28]; and treatment with estrogen protects against the transmission of simian immunodeficiency virus (SIV) [12]. Beta-estradiol inhibited HIV-1 replication by inhibition infection through inducing higher expression of chemokines [29, 30].

The associations of gender and serum total cholesterol on HIV replication in vivo are not well investigated. Thus, this study was designed to investigate the association of gender and serum total cholesterol with CD4+ $\mathrm{T}$ cell count and viral load in ART naïve study participants. The outcome of the study is important to understand the association of gender and serum total cholesterol on HIV RNA load and CD4+ T cell count in vivo. This will have a potential importance to provide a basis for therapeutic strategies to control HIV-1 replication and infection.

\section{Methods}

\section{Study setting, design and population}

This cross-sectional study was conducted from February to August 2013 in Addis Ababa, Ethiopia, at All African Leprosy Rehabilitation and Training Centre (ALERT), St. Paul, Yekatit-12 and Zewditu Memorial Hospitals. A total of 594 study participants who are adults (age $\geq 18$ ) and were ART naïve, enrolled for care in HIV care centres and waiting for ART drugs until they become eligible and willing to participate in the study were recruited consecutively. If the need for treatment of opportunistic infections arises, they were treated by chemoprophylaxis. This study was part of a bigger study that was planned to investigate the role of immune response on viral diversity of HIV-infected ART naïve patients. Institutional Research Ethics Review Committee (IRERC) of participating Institutions and the National Ethical Review Committee, Ministry of Science and Technology with reference number 3.10/004/2015 (Additional file 1: Figure S1) had approved the study. Enrolment of each study participant was done after giving full information and informed consent collected by anti-retroviral treatment nurses under close supervision of the principal investigator (MA). Patients with cognitive impairment and immediate intensive care requirement and pregnant women were excluded because we were bound to take only small amount of blood for those individuals that were not sufficient to the whole components of the study. Individuals who were taking drugs that could interfere with serum lipid levels during the study period were also excluded.

\section{Haematological and biochemical assays}

Automated FACS counter (Becton and Dickinson, San Jose, CA, USA) was employed to determine CD4+ T cell count. Sysmex-21 (Sysmex, KX-21 N, Kobe, Japan) blood analyzer by noncyanide method was used to quantify hemoglobin. Cut values of $<12 \mathrm{~g} / \mathrm{dL}$ in women and $<13 \mathrm{~g} /$ $\mathrm{dL}$ in men were considered anemic [31]. Enzymatic colorimetric method (Human diagnostics, HumanStar 180, Wiesbaden, Germany) was used to determine fasting 
serum cholesterol. Those study participants with serum cholesterol levels $\geq 200 \mathrm{mg} / \mathrm{dL}$ were defined as hypercholesterolemic [32].

\section{HIV RNA load determination}

Abbott HIV-1 assay (Abbott Molecular Inc., Des Plaines, IL, USA) was used to determined HIV RNA load in $200 \mu \mathrm{L}$ plasma.

\section{Questionnaire}

Information on clinical, socio-demographic and anthropometry were collected from patients' medical chart and triangulated by means of additional structured questionnaire on the day of blood sample collection (Additional file 2: Table S1).

\section{Anthropometric measurements}

Body mass index (BMI) cut offs for nutritional status as thinness or acutely malnutrition $\left(\mathrm{BMI}<18.5 \mathrm{~kg} / \mathrm{m}^{2}\right)$, normal $\left(B M I=18.5-24.9 \mathrm{~kg} / \mathrm{m}^{2}\right)$, overweight $(B M I=25.0-$ $29.9 \mathrm{~kg} / \mathrm{m}^{2}$ ) and obese (BMI $\geq 30 \mathrm{~kg} / \mathrm{m}^{2}$ ) were used [33].

\section{Data analysis}

The questionnaire and laboratory tests results (Additional file 3) were analyzed using STATA version 11.0 (Stata Corp, College station, Texas, USA) and GraphPad Prism version 5.03 (GraphPad software, California, USA). Frequency counts, percentages; mean \pm standard deviation (SD) and median with inter quartile range (IQR) were presented. The independent t-test or analysis of variance (ANOVA) tests were used to compare means. Spearman rank order correlation between log viral load, CD4+ T cell count, BMI, cholesterol and hemoglobin level were done. In addition, Pearson chi-square to test the associations was used to analyze categorical data. Diagnostics performance of anemia, low serum total cholesterol and the two markers together for predicting CD4+ T cell count or WHO clinical stage, and HIV RNA load categories were analyzed using test agreement (kappa value) and Spearman rank order correlation. Risk factors for HIV RNA load were identified using univariate (for crude coefficient, $\beta$ ) and then multivariate linear regression analysis (for adjusted coefficient, $\beta$ ) after adjusting for potential cofounders. In addition, risk factors that were found to be statistically significant by chi-square test were analyzed using univariate for crude odds ratio (COR) and then for multivariate logistic regression analysis for adjusted odds ratio (AOR) to adjust for potential cofounders for CD4 T cell count and/or WHO HIV stage categories $(\mathrm{CD} 4<$ 200 and/or stages III/IV, CD $4<350$ and/or stages III/ IV and CD $4<500$ and/or stages III/IV).

\section{Results}

Characteristics of the study population

As indicated in Table 1, 423 (71.2\%) of the study participants enrolled in the study were women. The median age of the whole study participants was 34 years. In addition, the median ages 37 and 32 were for men and women, respectively $(p<0.001)$. The total proportion of study participants at AIDS stage or WHO clinical stages III/IV were $25.9 \%$ among which $14.4 \%$ were at WHO clinical stages III/IV. The median CD4+ T cell count $\geq 200$ cells $/ \mathrm{mm}^{3}$ for $\sim 83 \%$ of the study participants were 357 cells $/ \mathrm{mm}^{3}$ (IQR $\left.=248-537\right)$; and had HIV RNA load for 500 study participants with detectable viral load of mean \pm SD of $4.23 \pm 0.83 \log$ copies $/ \mathrm{mL}$. From the total study participants, $74(12.3 \%)$ were found to have HIV RNA load below detectable limit $(<150$ copies $/ \mathrm{mL})$ and it was not done for $10(1.7 \%)$ due to sample limitation. Generally, the study participants were found $5.4 \%$ obese, $16.7 \%$ overweight and $15.1 \%$ undernourished. The prevalence of hypercholesterolemia in the study population was $16.7 \%$. The anemia prevalence was $11.2 \%$ in the whole study population. It was $12.8 \%$ in men and $10.6 \%$ in women $(p>0.05)$. In addition, length of time when about $74 \%$ of study participants stay positive knowing their sero-positive status was more than a year.

\section{HIV RNA load correlated with some variables}

As indicated in Fig. 1 below, CD4+ T cell count $(r=-0.412$, $p<0.01)$, body mass index $(r=-0.170, p<0.01)$ and total cholesterol concentrations $(r=-0.249, p<0.01)$ were found significantly correlated with HIV RNA load. However, hemoglobin concentrations were not significantly associated with HIV RNA load $(r=-0.084, p>0.05)$.

\section{Independent predictors of HIV RNA load}

Independent $\mathrm{t}$-test revealed that mean HIV RNA load was found significantly higher in men, and in study participants with serum total cholesterol $<200 \mathrm{mg} / \mathrm{dL}$. In addition, the mean HIV RNA load was found to be different between $\mathrm{CD} 4+\mathrm{T}$ cell count and/or WHO clinical stage categories, and anemic or normal (Table 2, $p<0.05$ ).

The association of each independent variable with dependent variable (log HIV RNA load) was analyzed by univariate linear regression analysis. As shown in Table 2, gender, CD4+ T cell count and/or WHO clinical stage categories, being anemic or normal, and being hypercholesterolemia or normal were found significantly associated with HIV RNA load $(p<0.05)$ and they were considered for multivariate linear regression analysis to determine the independent predictors of HIV RNA load.

The multivariate linear regression analysis showed that gender, CD4+ T cell count and/or WHO clinical stage categories, being anemic or normal, being hypercholesterolemia or normal were found to be independent 
Table 1 Characteristics of ART naïve study participants, February-September 2013, Addis Ababa, Ethiopia

\begin{tabular}{|c|c|c|}
\hline Variables & Number & $\%(C l$ 95\%) \\
\hline \multicolumn{3}{|l|}{ Gender } \\
\hline Male & 171 & $28.8(22.0-35.6)$ \\
\hline Female & 423 & $71.2(66.9-75.5)$ \\
\hline \multicolumn{3}{|l|}{ Marital status } \\
\hline Never married & 109 & $18.4(11.1-25.7)$ \\
\hline $\begin{array}{l}\text { Married/living } \\
\text { with partner }\end{array}$ & 293 & $49.3(43.6-55.0)$ \\
\hline $\begin{array}{l}\text { Divorced/widowed/ } \\
\text { separated }\end{array}$ & 192 & $32.3(25.7-38.9)$ \\
\hline \multicolumn{3}{|l|}{ BMI $\left(\mathrm{kg} / \mathrm{m}^{2}\right)$} \\
\hline$<18.5$ & 87 & $15.1(7.6-22.6)$ \\
\hline $18.5-24.9$ & 362 & $62.8(57.8-67.8)$ \\
\hline $25.0-29.9$ & 96 & $16.7(9.2-24.2)$ \\
\hline$\geq 30$ & 31 & $5.4(-2.6-13.4)$ \\
\hline \multicolumn{3}{|l|}{ Length of time stay positive (years) } \\
\hline$<1$ & 150 & $26.1(19.1-33.1)$ \\
\hline $1-3$ & 177 & $30.8(23.8-37.4)$ \\
\hline$>3$ & 248 & $43.1(37.1-49.5)$ \\
\hline \multicolumn{3}{|l|}{ WHO clinical stage } \\
\hline Stage 1 & 328 & $55.6(50.2-61.0)$ \\
\hline Stage 2 & 177 & $30.0(23.2-36.8)$ \\
\hline Stage $3 / 4$ & 85 & $14.4(6.9-21.9)$ \\
\hline \multicolumn{3}{|l|}{ CD4+ T cell count (cells/mm3) } \\
\hline$<200$ & 102 & $17.2(9.9-24.5)$ \\
\hline $200-349$ & 182 & $30.6(23.8-37.3)$ \\
\hline $350-499$ & 144 & $24.2(17.2-31.2)$ \\
\hline$\geq 500$ & 166 & $28.0(21.2-34.8)$ \\
\hline \multicolumn{3}{|l|}{ Hemoglobin level (g/dl) } \\
\hline Non-anemic & 507 & $88.8(86.1-91.5)$ \\
\hline Anemic & 64 & $11.2(3.5-18.9)$ \\
\hline \multicolumn{3}{|l|}{ Cholesterol level (mg/dl) } \\
\hline$\leq 200$ & 472 & $83.3(79.9-86.7)$ \\
\hline$>200$ & 95 & $16.7(9.2-24.2)$ \\
\hline \multicolumn{3}{|l|}{ HIV RNA load (copies/mL) } \\
\hline$<10,000$ & 427 & $45.2(39.2-51.2)$ \\
\hline$\geq 10,000$ & 157 & $54.8(49.3-60.3)$ \\
\hline $\begin{array}{l}\text { HIV RNA load in log copies/mL } \\
\text { (mean } \pm \text { standard deviation) }\end{array}$ & 500 & $4.23 \pm 0.83$ \\
\hline
\end{tabular}

predictors of HIV RNA load (Table 2, $p<0.05$ ). Women are at lower risk of having higher HIV RNA load in comparison to men. Having higher total cholesterol was found to be associated with reduced HIV RNA load in comparison to those with lower total cholesterol in serum. In addition, study participants with CD4+ T cell count $<500$ cells $/ \mathrm{mm}^{3}$ and/or stages III/IV and who are anemic were found to be risk factors for increase of HIV RNA load. To prove whether gender, CD4 cell count < 500 cells $/ \mathrm{mm}^{3}$ and/or WHO clinical stages III/IV, anemia and lower serum total cholesterol were also predictors of HIV RNA load along the three categories, binomial logistic regression analysis was done. CD4+ $\mathrm{T}$ cell count $<500$ cells $/ \mathrm{mm}^{3}$ and/or WHO clinical stages, and anemia were found to be significantly associated with the three HIV RNA categories. In addition, gender and low serum total cholesterol were found to be associated significantly with HIV RNA $\geq 10,000$ and $\geq 40,000$ copies/mL. However, gender and low serum total cholesterol were not found to be associated with HIV RNA $\geq 100,000$ copies/mL $(p>0.05)$.

\section{Independent predictors of CD4+ T cell count and/or WHO clinical stages}

As indicated in Fig. 2, Mann-whitney test between the median values CD4+ T cell count along gender, groups of HIV RNA load and serum total cholesterol, and being anemic or normal were done. The median (interquartile range) values of $\mathrm{CD} 4+\mathrm{T}$ cell count were found to be [296(263-323) and 386(364-414), $p<0.001]$ for men and women, [385(364-409) and 195(164-249), $p<$ 0.001 ] for HIV RNA load $<10,000$ - and $\geq 10,000$ cop$\mathrm{ies} / \mathrm{mL}, \quad[352(326-365)$ and 457(368-502), $p<0.001]$ for serum total cholesterol $<200-$ and $\geq 200 \mathrm{mg} / \mathrm{dL}$, and [258(206-313) and 366(354-389), $p<0.001]$ for being anemic and non-anemic, respectively.

As indicated in Tables 3 and 4, the Chi-square test or the univariate binomial logistic regression showed that gender, HIV RNA load, hemoglobin and serum total cholesterol levels were found to be associated with all the three categories of CD4+ T cell count and/or WHO clinical stages $(p<0.05)$. Multivariate binomial logistic regression analysis (Table 5) showed gender and HIV RNA load $\geq 10,000$ to be independently associated with CD4+ T cell count and/or WHO clinical stage categories. In addition, anemia and low serum total cholesterol were found to be independently associated with CD4 T cell count $<200$ and/or stages III/IV $(p<0.05)$. However, anemia and low serum total cholesterol were not significantly associated with CD4 $\mathrm{T}$ cell count $<350$ and/or stages III/IV, and CD4 $\mathrm{T}$ cell count $<500$ and/or stages III/IV $(p>0.05)$.

Spearman's rank order correlation (r) and $p$-value of each variable with CD4+ T cell count and/or WHO clinical stage, and HIV RNA load categories were done as shown in Additional file 4: Table S2. The correlations range from relatively small to moderate. Anemia, low serum total cholesterol and the combination of the two markers were found with significant but small correlation $(r<0.3, p<0.05)$. Furthermore, CD $4+\mathrm{T}$ cell count 

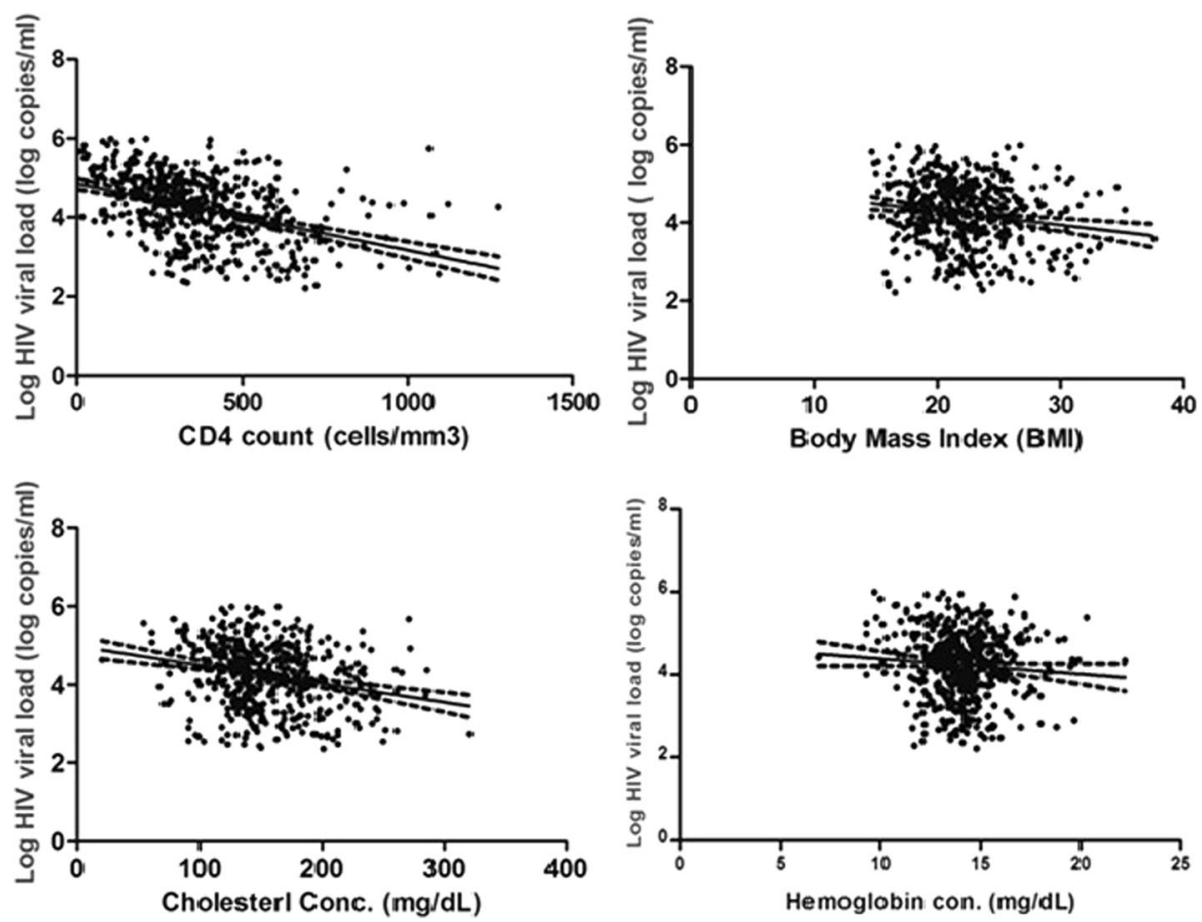

Fig. 1 The correlation of log HIV RNA load with CD4+ T cell, BMl, total cholesterol and hemoglobin. The significant Pearson correlation $(p<0.01)$ between log HIV RNA load, and CD4+ T cell count, body mass index, serum total cholesterol (TC) and hemoglobin level of HIV-infected ART naïve study participants in Addis Ababa, Ethiopia

and/or WHO clinical stages, and HIV RNA load categories were also found to have significant moderate correlation between them $(0.3<r<0.5, p<0.01)$.

\section{Diagnostics performance of alternative markers to HIV disease progression}

Diagnostics performance (sensitivity, specificity and predictive values) of HIV RNA load $\geq 10,000$ or CD4 T cell count $<500$ and/or Stage III/IV, anemia, lower serum total cholesterol, and combination of anemia and lower serum total cholesterol were done to determine disease progression as shown in Table 6. HIV RNA load $\geq 10,000$ and CD4 $\mathrm{T}$ cell count $<500$ and/or stages III/IV had a better sensitivity and specificity to determine disease progression. Low serum total cholesterol alone, and the combination of anemia and lower serum total cholesterol showed high sensitivities of $>80.0$ but low specificities. Lower serum total cholesterol was better than HIV RNA load $\geq 10,000$ and CD4 $T$ cell count $<500$ and/or stages III/IV in its sensitivity, but low in its specificity to determine disease progression. Anemia did not have good diagnostic performance when used alone because the sensitivity was low even if the specificity was high. Low positive predictive values (PPV) and high negative predictive values (NPV) were observed in CD4 T cell count $<200$ and/or stage III/IV. PPV value improved but NPV reduced in categories CD4 T cell count $<350$ and/ or stages III/IV, and CD4 $\mathrm{T}$ cell count $<500$ and/or stages III/IV. However, it was the opposite of the CD4+ $\mathrm{T}$ cell count and/or WHO clinical stage categories that happened to the PPV and NPV in HIV RNA load categories (Table 6).

\section{Discussion}

This study was designed to investigate the association of gender and serum total cholesterol with $\mathrm{CD} 4+\mathrm{T}$ cell count and/or WHO HIV stages III/IV, and the HIV RNA load in antiretroviral-naïve individuals with known time of staying HIV-positive in Addis Ababa, Ethiopia.

In concordance with other in vivo studies, this study showed that those study participants with high serum total cholesterol have lower HIV RNA load. This inhibition of HIV replication in study participants with high serum total cholesterol could be due to the production of oxysterols $[24,25]$. In addition, the effect of ART is found impaired in hypocholesterolemic HIV-infected patients [34]. Viral infection induced IFNs up-regulate ISGs (for example, cholesterol-25-hydroxylase) and cause down-regulation of sterol biosynthesis to protect the cells $[22,26] .25-\mathrm{HC}$ as one of the oxysterols inhibits viral entry by blocking membrane fusion and controlling sterol biosynthesis $[23,24,30]$. However, in vitro studies showed discordance results in comparison with our study that higher serum total cholesterol is required for efficient 
Table 2 Associations of variables with HIV RNA load among ART-naïve study participants in Addis Ababa, Ethiopia

\begin{tabular}{|c|c|c|c|}
\hline Variables & Log HIV RNA load (Mean \pm SD) & Univariate, $\beta$ (95\% Cl) & Multivariate, $\beta(95 \% \mathrm{Cl})$ \\
\hline \multicolumn{4}{|l|}{ Gender } \\
\hline Male & $4.49 \pm 0.76^{\mathrm{a}}$ & Ref. & Ref. \\
\hline Female & $4.11 \pm 0.84$ & $-0.38(-0.54,-0.23)^{\mathrm{a}}$ & $-0.24(-0.40,-0.07)^{b}$ \\
\hline \multicolumn{4}{|c|}{ CD4+ T cell count and/or stages III/IV } \\
\hline$\geq 500$ and/or not stages III/IV & $3.73 \pm 0.82^{\mathrm{a}}$ & Ref. & Ref. \\
\hline$<500$ and/or stages III/IV & $4.36 \pm 0.79$ & $0.63(0.46,0.80)^{\mathrm{a}}$ & $0.56(0.38,0.73)^{\mathrm{a}}$ \\
\hline \multicolumn{4}{|l|}{ Hemoglobin conc. (g/dL) } \\
\hline Non-anemic & $4.18 \pm 0.81^{c}$ & Ref. & Ref. \\
\hline Anemic & $4.68 \pm 0.79$ & $0.50(0.27,0.73)^{\mathrm{a}}$ & $0.41(0.18,0.64)^{b}$ \\
\hline \multicolumn{4}{|l|}{ Total cholesterol conc. (mg/dL) } \\
\hline$\geq 200$ & $3.85 \pm 0.78$ & Ref. & Ref. \\
\hline$<200$ & $4.31 \pm 0.82^{c}$ & $-0.46(-0.67,-0.25)^{\mathrm{a}}$ & $-0.25(-0.45,-0.04)^{c}$ \\
\hline Variables & $\geq 10,000$, AOR $(95 \% \mathrm{Cl})$ & $\geq 40,000$, AOR $(95 \% \mathrm{Cl})$ & $\geq 100,000, \operatorname{AOR}(95 \% \mathrm{Cl})$ \\
\hline \multicolumn{4}{|l|}{ Gender } \\
\hline Male & 1.00 & 1.00 & 1.00 \\
\hline Female & $0.51(0.33-0.79)$ & $0.52(0.34-0.79)$ & $0.64(0.41-1.08)^{*}$ \\
\hline \multicolumn{4}{|c|}{ CD4+ T cell count and/or stages III/IV } \\
\hline$\geq 500$ and/or not stages III/IV & 1.00 & 1.00 & 1.00 \\
\hline$<500$ and/or stages III/IV & $4.44(2.86-6.90)$ & $5.29(2.90-9.64)$ & $5.36(2.26-12.70)$ \\
\hline \multicolumn{4}{|l|}{ Hemoglobin conc. (g/dL) } \\
\hline Non-anemic & 1.00 & 1.00 & 1.00 \\
\hline Anemic & $2.85(1.44-5.66)$ & $2.72(1.52-4.85)$ & $2.46(1.34-4.51)$ \\
\hline \multicolumn{4}{|l|}{ Total cholesterol conc. (mg/dL) } \\
\hline$\geq 200$ & 1.00 & 1.00 & 1.00 \\
\hline$<200$ & $2.22(1.32-3.74)$ & $2.65(1.36-5.17)$ & $2.35(0.97-5.69)^{*}$ \\
\hline
\end{tabular}

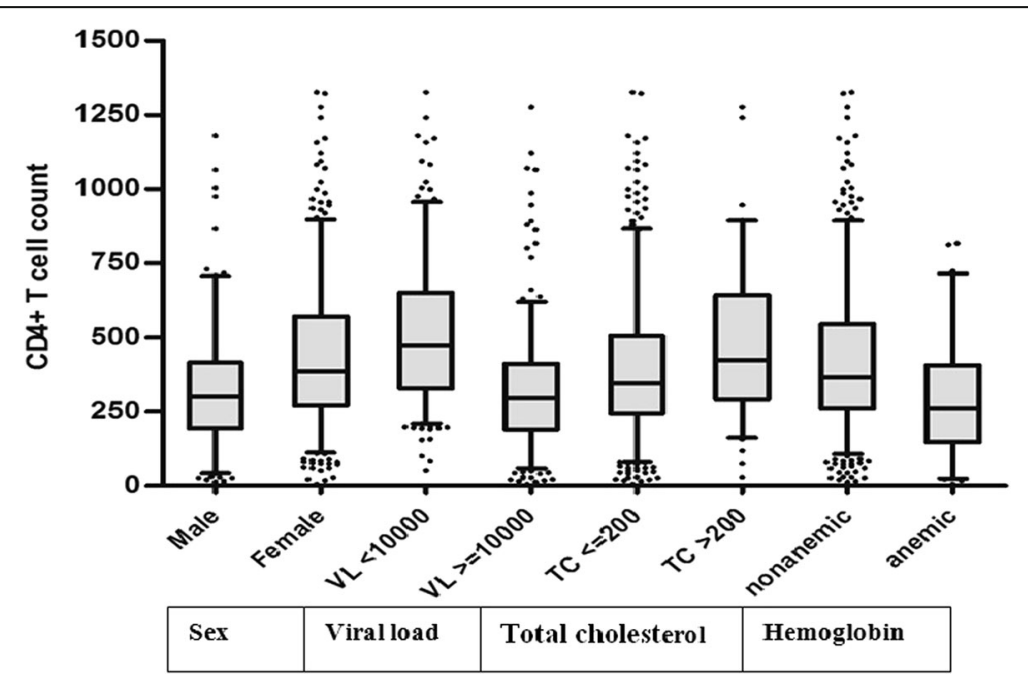

Fig. 2 CD4+ T cell count by gender, HIV RNA load, serum total cholesterol (TC) and hemoglobin 
Table 3 Chi-square associations of variables with immune status among ART-naïve study participants in Addis Ababa, Ethiopia

\begin{tabular}{|c|c|c|c|c|}
\hline Variables & $\begin{array}{l}\text { Overall } \\
\text { [Number (\%)] }\end{array}$ & $\begin{array}{l}\text { CD4 < } 200 \text { or stage III/IV } \\
{[\text { Number }(\%)]}\end{array}$ & $\begin{array}{l}\text { CD4 < } 350 \text { or stage III/IV } \\
{[\text { Number }(\%)]}\end{array}$ & $\begin{array}{l}\text { CD4 < } 500 \text { or stage III/IV } \\
{[\text { Number (\%)] }}\end{array}$ \\
\hline \multicolumn{5}{|l|}{ Gender } \\
\hline Male & $171(28.8)$ & $64(41.6)^{a}$ & $111(35.5)^{a}$ & $147(33.7)^{a}$ \\
\hline Female & $423(71.2)$ & $90(58.4)$ & $202(64.5)$ & $289(66.3)$ \\
\hline \multicolumn{5}{|c|}{ HIV RNA load (copies/mL) } \\
\hline$<10,000$ & $264(45.2)$ & $27(17.9)^{a}$ & $84(27.4)^{a}$ & $149(34.8)^{a}$ \\
\hline$\geq 10,000$ & $320(54.8)$ & $124(82.1)$ & 223(72.6) & $279(65.2)$ \\
\hline \multicolumn{5}{|c|}{ Hemoglobin conc. (g/dL) } \\
\hline Non-anemic & $507(88.8)$ & $117(78.5)^{a}$ & $252(83.7)^{a}$ & $362(86.6)^{b}$ \\
\hline Anemic & $64(11.2)$ & $32(21.5)$ & $49(16.3)$ & $56(13.4)$ \\
\hline \multicolumn{5}{|c|}{ Total cholesterol conc. (mg/dL) } \\
\hline$>200$ & $95(16.6)$ & $9(6.2)$ & $34(11.4)^{a}$ & $56(13.4)^{b}$ \\
\hline$\leq 200$ & $476(83.4)$ & $136(93.8)^{a}$ & 264(88.6) & $362(86.6)$ \\
\hline
\end{tabular}

Note: ${ }^{\text {a }}{ }^{\text {b }}$ refer to $p$ value $<0.001$ and $<0.01$, respectively

viral replication. This role of cholesterol is clearly proved by inhibiting the cholesterol biosynthesis or depletion of cellular cholesterol content by stimulation of cholesterol efflux by ABCA1 that decrease virus entry and replication [15, 20,21]. HIV plays increasing of cholesterol in cells through Nef protein that inhibits activity ABCA1 that impairs cholesterol efflux [16-18], and induces genes involved in cholesterol biosynthesis [17]. These differences in cholesterol role in vitro and in vivo indicate that it works differently in cell-lines in culture and human subjects.

This study also showed that HIV RNA load is higher in men than women. This may be because women produce higher antibody- and cell-mediated immune responses following either infection or vaccination than men that avoids infection and/or inhibits replication of the pathogens in the host [13]. With regard to the fluctuations of hormone level during menstrual cycle, in the follicular phase high estrogen levels and higher immunity may have protective effects against invading pathogens. During the luteal phase, however, high progesterone levels and reduced immunity may favor microbial invasion $[14,35]$. The study done with estrogen treatment protects female rhesus macaques against the transmission of SIV by thickening of the genital tract mucosal tissue [12]. In addition, in vitro study demonstrated that beta-estradiol inhibited HIV-1 replication in human peripheral blood lymphocytes [29] by inhibiting target cell infection that involves cell-entry through higher expression of chemokines [30]. On the other hand, cells of the immune system in individuals with hypercholesterolemia had greater phagocytic activity,

Table 4 Univariate associations of variables with immune status among ART-naïve study participants in Addis Ababa, Ethiopia

\begin{tabular}{|c|c|c|c|}
\hline Variables & $\begin{array}{l}\mathrm{CD} 4<200 \text { and/or } \\
\text { stages III/IV, } \\
\text { AOR }(95 \% \mathrm{Cl})\end{array}$ & $\begin{array}{l}\text { CD4 }<350 \text { and/or } \\
\text { stages III/IV, } \\
\text { AOR }(95 \% \text { Cl) }\end{array}$ & $\begin{array}{l}\text { CD4 < } 500 \text { and/or } \\
\text { stages III/IV, } \\
\text { AOR }(95 \% \text { Cl) }\end{array}$ \\
\hline \multicolumn{4}{|l|}{ Gender } \\
\hline Male & 1.00 & 1.00 & 1.00 \\
\hline Female & $0.45(0.31-0.67)$ & $0.49(0.34-0.71)$ & $0.35(0.22-0.57)$ \\
\hline \multicolumn{4}{|c|}{ HIV RNA load (copies/mL) } \\
\hline$<10,000$ & 1.00 & 1.00 & 1.00 \\
\hline$\geq 10,000$ & $5.55(3.52-8.77)$ & $5.00(3.51-7.12)$ & 5.25(3.49-7.90) \\
\hline \multicolumn{4}{|c|}{ Hemoglobin conc. (g/dL) } \\
\hline Non-anemic & 1.00 & 1.00 & 1.00 \\
\hline Anemic & $3.33(1.96-5.67)$ & $3.27(1.79-5.98)$ & $2.80(1.3-6.03)$ \\
\hline \multicolumn{4}{|c|}{ Total cholesterol conc. (mg/dL) } \\
\hline$>200$ & 1.00 & 1.00 & 1.00 \\
\hline$\leq 200$ & $3.82(1.87-7.81)$ & $2.27(1.43-3.58)$ & $2.21(1.40-3.50)$ \\
\hline
\end{tabular}


Table 5 Multivariate associations of variables with immune status among ART-naïve study participants in Addis Ababa, Ethiopia

\begin{tabular}{|c|c|c|c|}
\hline Variables & $\begin{array}{l}\text { CD4 }<200 \text { and/or } \\
\text { stages III/IV, } \\
\text { AOR }(95 \% \text { Cl) }\end{array}$ & $\begin{array}{l}\text { CD4<350 and/or } \\
\text { stages III/IV, } \\
\text { AOR }(95 \% \text { Cl) }\end{array}$ & $\begin{array}{l}\text { CD4 }<500 \text { and/or } \\
\text { stages III//V, } \\
\text { AOR }(95 \% \text { Cl) }\end{array}$ \\
\hline \multicolumn{4}{|l|}{ Gender } \\
\hline Male & 1.00 & 1.00 & 1.00 \\
\hline Female & $0.58(0.36-0.95)$ & $0.60(0.36-0.99)$ & $0.38(0.19-0.73)$ \\
\hline \multicolumn{4}{|c|}{ HIV RNA load (copies/mL) } \\
\hline$<10,000$ & 1.00 & 1.00 & 1.00 \\
\hline$\geq 10,000$ & $3.89(2.34-6.46)$ & $4.09(2.80-6.00)$ & $4.49(2.69-7.49)$ \\
\hline \multicolumn{4}{|c|}{ Hemoglobin conc. (g/dL) } \\
\hline $\begin{array}{l}\text { Non- } \\
\text { anemic }\end{array}$ & 1.00 & 1.00 & 1.00 \\
\hline Anemic & $2.39(1.28-4.46)$ & $1.73(0.86-3.56)^{*}$ & $1.67(0.65-4.28)^{*}$ \\
\hline \multicolumn{4}{|c|}{ Total cholesterol conc. (mg/dL) } \\
\hline$>200$ & 1.00 & 1.00 & 1.00 \\
\hline$\leq 200$ & $2.14(1.01-4.59)$ & $1.53(0.90-2.54)^{*}$ & $1.38(0.75-2.56)^{*}$ \\
\hline
\end{tabular}

more circulating lymphocytes, more total $\mathrm{T}$ cells, more $\mathrm{CD} 8+\mathrm{T}$ cells, more immunoglobulin production, more proliferation and differentiation, and migration of lymphocytes than from individuals with lower cholesterol levels [36-38]. This could be explained by the role of intermediates in the cholesterol-biosynthetic pathway and downstream oxysterol metabolites that have been found to influence diverse functions of cells of the immune system. However, significant gender differences in HIV RNA levels and CD4 counts are reported in HIV-infected children before the onset of puberty. These data indicate that intrinsic genetic differences between male and female individuals, unrelated to sex steroid hormone levels, influence HIV RNA level and CD4 parameters in HIV-infected individuals [39]. This may be possibly explained by epigenetic differences between the two genders [40, 41] even if the mechanism how epigenetic differences affect is not well clear.

Low serum total cholesterol and its combination with anemia showed high sensitivities of $>80.0$ but low specificities in predicting disease progression (Table 6). The weak correlations, the low sensitivities and specificities, and the high fluctuation in PPVs and NPVs of this study may be partly explained by high background prevalences the general population of other non-HIV-related causes. For instance, anemia cannot distinguish between early and advanced HIV disease progression in high prevalence of infections and undernutrition [2, 42]. In addition, study participants were eligible for ART treatment when CD4 $+\mathrm{T}$ cell count $<200$ cells $/ \mathrm{mm}^{3}$ and/or WHO clinical stages III/IV according to the Ethiopian
Table 6 Diagnostics performance of alternative biomarkers in reference with CD4+ T-cell count and/or WHO clinical stages, and HIV RNA load categories among ART-naïve study participants in Addis Ababa, Ethiopia

\begin{tabular}{|c|c|c|c|c|}
\hline & Sensitivity & Specificity & PPV & NPV \\
\hline Variables & \multicolumn{4}{|c|}{ CD4 < 200 and/or stages III/IV } \\
\hline HIV RNA load $\geq 10,000$ & 82.1 & 54.7 & 38.8 & 89.8 \\
\hline Anemia & 21.5 & 92.4 & 50.0 & 76.9 \\
\hline Cholesterol $<200$ & 93.8 & 20.2 & 28.6 & 90.5 \\
\hline \multirow[t]{2}{*}{ Anemia and/or cholesterol $<200$} & 85.1 & 24.5 & 28.3 & 82.4 \\
\hline & \multicolumn{4}{|c|}{ CD4 <350 and/or stages III/IV } \\
\hline HIV RNA load $\geq 10,000$ & 72.6 & 65.3 & 70.1 & 68.1 \\
\hline Anemia & 16.2 & 94.4 & 76.6 & 50.0 \\
\hline Cholesterol $<200$ & 88.6 & 22.6 & 55.8 & 64.2 \\
\hline \multirow[t]{2}{*}{ Anemia and/or cholesterol $<200$} & 81.8 & 26.6 & 55.7 & 56.5 \\
\hline & \multicolumn{4}{|c|}{ CD4 $<500$ and/or stages III/IV } \\
\hline HIV RNA load $\geq 10,000$ & 65.2 & 73.7 & 87.2 & 43.6 \\
\hline Anemia & 13.4 & 94.8 & 87.5 & 28.6 \\
\hline Cholesterol $<200$ & 86.6 & 25.5 & 76.1 & 41.1 \\
\hline \multirow[t]{2}{*}{ Anemia and/or cholesterol $<200$} & 80.5 & 29.1 & 75.8 & 35.1 \\
\hline & \multicolumn{4}{|c|}{ HIV RNA load $\geq 10,000$} \\
\hline CD4 $<500$ and/or stages III/IV & 87.2 & 43.6 & 65.2 & 73.7 \\
\hline Anemia & 16.1 & 94.8 & 79.4 & 47.8 \\
\hline Cholesterol $<200$ & 89.9 & 24.7 & 58.9 & 67.0 \\
\hline \multirow[t]{2}{*}{ Anemia and/or cholesterol $<200$} & 84.1 & 29.9 & 59.3 & 60.8 \\
\hline & \multicolumn{4}{|c|}{ HIV RNA load $\geq 40,000$} \\
\hline CD4 < 500 and/or stages III/IV & 91.6 & 35.5 & 40.9 & 89.7 \\
\hline Anemia & 20.2 & 93.1 & 58.7 & 70.7 \\
\hline Cholesterol $<200$ & 93.5 & 22.4 & 36.8 & 87.6 \\
\hline \multirow[t]{2}{*}{ Anemia and/or cholesterol $<200$} & 86.9 & 26.7 & 36.6 & 80.8 \\
\hline & \multicolumn{4}{|c|}{ HIV RNA load $\geq 100,000$} \\
\hline CD4 $<500$ and/or stages III/IV & 92.0 & 30.6 & 21.5 & 94.9 \\
\hline Anemia & 22.7 & 91.2 & 34.9 & 84.9 \\
\hline Cholesterol $<200$ & 93.8 & 18.9 & 19.3 & 93.6 \\
\hline Anemia and/or cholesterol $<200$ & 87.0 & 24.2 & 19.2 & 90.0 \\
\hline
\end{tabular}

Note: PPV positive predictive value, $N P V$ negative predictive value

ART Guideline which was used during the study period [43]. In addition, about $83 \%$ of the study participants had CD $4+\mathrm{T}$ cell count $\geq 200$ cells $/ \mathrm{mm}^{3}$ and only $14.4 \%$ were at WHO clinical stages III/IV during the study period. The effect of ART is impaired in hypocholesterolemic HIV-infected patients [34]. This may signify the potential use of low serum total cholesterol as predicting marker of ART efficacy in this era of test and treat. These biomarkers may enhance the performance of the physicians to examine the prognosis of the disease accurately among patients on ART. It has been also noted that switches in therapy will not be easy if physicians 
only had CD4+ T cell count because CD4+ T cell recovery is not high enough mainly in those who start ART late [6]. Using alternate biomarkers for monitoring ART efficacy is very useful tool through prolonging the interval of testing CD4+ T cell count and HIV RNA load. Basic laboratory testing and competent clinical monitoring of alternative biomarkers will thus be highly helpful under these circumstances [44, 45].

The study has some limitations. The recruitment of the study population did not include patients with cognitive impairment and immediate intensive care requirement. In addition, there may be false report of the some study participant that they are ART naive. The other limitation of this study is the design. It was cross-sectional so that it is possible to identify associations but not causal relationships between risk and outcome variables. Therefore, there is need for prospective cohort or case control studies. In addition, serological evidence of hepatitis $\mathrm{B} / \mathrm{C}$, family history of dyslipidemia, changes in mood, depression, and factors related to lifestyle (smoking and physical inactivity) were unaccounted.

\section{Conclusions}

Gender and serum total cholesterol were found associated with CD4+ T cell count and/or WHO clinical stage, and HIV RNA load categories. There is a significant lower HIV RNA load and better CD4+ T cell count in women and those study participants with higher serum total cholesterol. Therefore, further study should be done to verify the causal relationship between gender and serum total cholesterol with CD4+ T cell count and HIV RNA load. Therefore, documentation of such studies on the relationships of gender and serum total cholesterol with immunity and HIV replication may provide a basis for therapeutic strategies to control HIV replication.

\section{Additional files}

Additional file 1: Figure S1. Ethical clearance. (PDF $582 \mathrm{~kb}$ )

Additional file 2: Table S1. Study participant demographic, socioeconomic, clinical and behavioral data collecting Questionnaire. (DOC $131 \mathrm{~kb}$ )

Additional file 3: Raw data. This additional file contains sociodemographic, clinical, immunological, virological, anthropometric and biochemical data of the study participants. (XLSX $66 \mathrm{~kb}$ )

Additional file 4: Table S2. Correlation of alternative biomarkers in reference with CD4+ T-cell count and/or WHO clinical stages, and HIV RNA load categories among ART-naive study participants in Addis Ababa, Ethiopia. (DOCX $13 \mathrm{~kb}$ )

\section{Abbreviations}

ABCA1: ATP binding cassette subfamily A member 1; AIDS: Acquired immune deficiency syndrome; ANOVA: Analysis of variance; AOR: Adjusted odds ratio; ART: Antiretroviral therapy; ATP: Adult Treatment Panel; BMI: Body mass index; Cl: Confidence interval; COR: Crude odds ratio; EDHS: Ethiopian demographic and health survey; HC: Hydroxycholesterol; HIV: Human immunodeficiency virus; IQR: Inter quartile range; IRERC: Institutional
Research Ethics Review committee; ISGs: Interferon-stimulated genes; NCEP: National Cholesterol Education Program; NPV: Negative predictive value; PPV: Positive predictive value; RNA: Ribonucleic acid; SIV: Simian immunodeficiency virus; TC: Total cholesterol; UNAIDS: Joint United Nations Program on HIV/AIDS; WHO: World Health Organization

\section{Acknowledgements}

Study participants, and clinicians and laboratory persons in ALERT, St. Paul, Yekatit-12 and Zewditu Memorial Hospitals who participated in the study are acknowledged.

\section{Funding}

The study was funded by Armauer Hansen Research Institute, Ethiopian Public Health Institute and Addis Ababa University. The funding bodies have not had a role in the design of the study, in data collection, analysis and interpretation of results, and in writing the manuscript.

\section{Availability of data and materials}

The unidentified data from this study is available as supporting information in within this research article.

\section{Authors' contributions}

MA participated in the conception, design of the study, coordinated the data collection, data analysis, and write up of the draft manuscript. RH, DK, AA and BP involved in the conception, design of the study, and review of the manuscript. All authors read and approved the final manuscript.

\section{Ethics approval and consent to participate}

The study was ethically cleared by the Institutional Research Ethics Review Committee (IRERC) of participating Institutions (Addis Ababa University, Armauer Hansen Research Institute, and ALERT, St. Paul, Yekatit-12 and Zewditu Memorial Hospitals) and the National Ethical Review Committee, Ministry of Science and Technology, Ethiopia, with reference number 3.10/004/2015 (Additional file 1: Figure S1). A written consent from study participants was sought and obtained.

Consent for publication

Not applicable

\section{Competing interests}

The authors declare that they have no competing interests.

\section{Publisher's Note}

Springer Nature remains neutral with regard to jurisdictional claims in published maps and institutional affiliations.

\section{Author details}

${ }^{1}$ Microbial, Cellular and Molecular Biology Department, Addis Ababa University, Addis Ababa, Ethiopia. ${ }^{2}$ Armauer Hansen Research Institute, Addis Ababa, Ethiopia. ${ }^{3}$ Ethiopian Public Health Institute, Addis Ababa, Ethiopia.

Received: 14 February 2018 Accepted: 16 July 2018

Published online: 31 July 2018

References

1. UNAIDS. AIDS Epidemic Update. Geneva; 2014.

2. Ethiopia Demographic and Health Survey (EDHS). Addis Ababa; 2011

3. HIV/AIDS Prevention and Control Office (HAPCO). Country progress report on the HIV response. Addis Ababa; 2014

4. Abebe A, Pollakis G, Fontanet AL, Fisseha B, Tegbaru B, Kliphuis A, et al. Identification of a genetic sub-cluster of the HIV-1 subtype $C\left(C^{\prime}\right)$ widespread in Ethiopia. AIDS Res Hum Retrovir. 2000;16:1909-14.

5. Kassu A, Fujino M, Matsuda M, Nishizawa M, Ota F, Sugiura W. Molecular epidemiology of HIV type 1 in treatment-naïve patients in North Ethiopia. AIDS Res Hum Retrovir. 2007;23:564-8.

6. WHO. Guideline on when to start antiretroviral therapy and on preexposure prophylaxis for HIV. Geneva; 2015.

7. Lorizate $M$, Kräusslich $\mathrm{H}$. Role of lipids in virus replication. Cold Spring Harb Perspect Biol. 2011;3:a004820.

8. Mazzon M, Mercer J. Lipid interactions during virus entry and infection. Cell Microbiol. 2014;16:1493-502. 
9. Negredo E, Puigdomenech I, Marfil S, Puig J, Perez-Alvarez N, Ruiz L, et al. Association between HIV replication and cholesterol in peripheral blood mononuclear cells in HIV-infected patients interrupting HAART. J Antimicrob Chemother. 2008;61:400-4.

10. Musiol A, Gran S, Ehrhardt C, Ludwig S, Grewal T, Gerke V, et al. Annexin A6balanced late endosomal cholesterol controls influenza a replication and propagation. MBio. 2013;4:e00608-13.

11. Klein SL. The effects of hormones on gender differences in infection: from genes to behavior. Neurosci Biobehav Rev. 2000;24:627-38.

12. Hel Z, Stringer E, Mestecky J. Sex steroid hormones, hormonal contraception, and the Immunobiology of human immunodeficiency Virus1 infection. Endocr Rev. 2010;31:79-97.

13. Beagley KW, Gockel CM. Regulation of innate and adaptive immunity by the female sex hormones oestradiol and progesterone. FEMS Immunol Med Microbiol. 2003:38:13-22.

14. Brügger B, Krautkramer E, Tibroni N, Munte CE, Rauch S, Leibrecht I, et al. Human immunodeficiency virus type 1 Nef protein modulates the lipid composition of virions and host cell membrane microdomains. Retrovirology. 2007;4:70-81

15. Morrow MP, Grant A, Mujawar Z, Dubrovsky L, Pushkarsky T, Kiselyeva Y, et al. Stimulation of the liver $X$ receptor pathway inhibits HIV-1 replication via induction of ATP-binding cassette transporter A1. Mol Pharmacol. 2010;78: 215-25.

16. Fitzgerald ML, Mujawar Z, Tamehiro N. ABC transporters, atherosclerosis and inflammation. Atherosclerosis. 2010;211:361-70.

17. van't Wout AB, Swain JV, Schindler M, Rao U, Pathmajeyan MS, Mullins Jl, et al. Nef induces multiple genes involved in cholesterol synthesis and uptake in human immunodeficiency virus type 1-infected T cells. J Virol. 2005;79: 10053-8.

18. Mujawar Z, Rose H, Morrow MP, Pushkarsky T, Dubrovsky L, Mukhamedova $\mathrm{N}$, et al. Human immunodeficiency virus impairs reverse cholesterol transport from macrophages. PLoS Biol. 2006;4:e365.

19. Arora VK, Fredericksen BL, Garcia JV. Nef: agent of cell subversion. Microbes Infect. 2002:4:189-99.

20. Chukkapalli V, Heaton NS, Randall G. Lipids at the interface of virus-host interactions. Curr Opin Microbiol. 2012:15:512-8.

21. Petersen J, Drake MJ, Bruce EA, Riblett AM, Didigu CA, Wilen CB, et al. The major cellular sterol regulatory pathway is required for Andes virus infection. PLoS Pathog. 2014;10:e1003911.

22. Blanc M, Hsieh WY, Robertson KA, Watterson S, Shui G, Lacaze P, et al. Host defense against viral infection involves interferon mediated downregulation of sterol biosynthesis. PLoS Biol. 2011;9:e1000598.

23. Holmes R, VandeBerg J, Cox L. Genomics and proteomics of vertebrate cholesterol ester lipase (LIPA) and cholesterol 25-hydroxylase $(\mathrm{CH} 25 \mathrm{H})$. Biotech. 2011;1:99-109.

24. Liu S, Aliyari R, Chikere K, Li G, Marsden MD, Smith JK, et al. Interferoninducible Cholesterol-25-hydroxylase broadly inhibits viral entry by production of 25-hydroxycholesterol. Immunity. 2013;38:92-105.

25. Cyster JG, Dang EV, Reboldi A, Yi T. 25-hydroxycholesterols in innate and adaptive immunity. Nat Rev Immunol. 2014;14:731-43.

26. Brown MS, Goldstein JL. Cholesterol feedback: from Schoenheimer's bottle to Scap's MELADL. J Lipid Res. 2009;50:S15-27.

27. Sterling TR, Vlahov D, Astemborski J, Hoover DR, Margolick JB, Quinn TC Initial plasma HIV-1 RNA levels and progression to AIDS in women and men. N Engl J Med. 2001;344:720-5.

28. Gandhi M, Bacchetti P, Miotti P, Quinn TC, Veronese F, Greenblatt RM. Does patient sex affect human immunodeficiency virus levels? Clin Infect Dis. 2002;35:313-22.

29. Zhang M, Huang Q, Huang Y, Wood O, Yuan W, Chancey C, et al. Betaestradiol attenuates the anti-HIV-1 efficacy of Stavudine (D4T) in primary PBL. Retrovirology. 2008;5:82-9.

30. Rodriguez-Garcia M, Biswas N, Patel MV, Barr FD, Crist SG, Ochsenbauer C, et al. Estradiol reduces susceptibility of CD4+ T cells and macrophages to HIV infection. PLoS One. 2013;8:e62069.

31. WHO. Indicators and strategies for Iron deficiency and anaemia programmes, report of a WHO/UNICEF/UNU Consultation. Geneva; 1994. p. 33-47.

32. Panel, National Cholesterol Education Program NCEP Expert. Third report of the National Cholesterol Education Program (NCEP) expert panel on detection, evaluation, and treatment of high blood cholesterol in adults (adult treatment panel III) final report. Circulation. 2002;106:3143.
33. WHO Physical Status. The use and interpretation of anthropometry; report of a WHO expert committee. Geneva; 1995. http://www.who.int/iris/handle/ $10665 / 37003$

34. Miguez MJ, Lewis JE, Bryant VE, Rosenberg R, Burbano X, Fishman J, et al. Low cholesterol? Don't brag yet ... Hypocholesterolemia blunts HAART effectiveness: a longitudinal study. J Int AIDS Soc. 2010;13:25-34.

35. Brambilla F, Speca A, Pacchiarotti I, Biondi M. Hormonal background of physiological aggressiveness in psychologically healthy women. Int J Psychophysiol. 2010;75:291-4.

36. Hannedouche S, Zhang J, Yi T, Shen W, Nguyen D, Pereira JP, et al. Oxysterols direct immune cell migration via EBI2. Nature. 2011;475:524-7.

37. Liu C, Yang XV, Wu J, Kuei C, Mani NS, Zhang L, et al. Oxysterols direct B-cell migration through EBI2. Nature. 2011;475:519-23.

38. Muldoon MF, Marsland A, Flory JD, Rabin BS, Whiteside TL, Manuck SB. Immune system differences in men with hypo- or hypercholesterolemia. Clin Immunol Immunopathol. 1997:84:145-9.

39. Ruel TD, Zanoni BC, Sewanyana I, Cao H, Havlir DV, Kamya M, et al. Sex differences in HIV RNA level and CD4 cell percentage during childhood. CID. 2011;53:592-9.

40. Ellegren H, Parsch J. The evolution of sex-biased genes and sex-biased gene expression. Nat Rev Genet. 2007;8:689-98.

41. Ober C, Loisel DA, Gilad Y. Sex-specific genetic architecture of human disease. Nat Rev Genet. 2008;9:911-22.

42. Brown M, Kizza M, Watera C, Quigley MA, Rowland S, Hughes P, et al. Helminth infection is not associated with faster progression of HIV disease in coinfected adults in Uganda. J Infec Dis. 2004;190:1869-79.

43. HAPCO. Guidelines for anti retroviral treatment in adults and adolescents. Addis ababa; 2007.

44. Collini P, Schwab U, Sarfo S, Obeng-Baah J, Norman B, Chadwick D, et al. Sustained immunological responses to highly active antiretroviral therapy at 36 months in a Ghanaian HIV cohort. Clin Infect Dis. 2009:48:988-91.

45. Kandi V, Bashir A. Advantages of alternate biomarkers in the Management of Human Immunodeficiency Virus with highly active antiretroviral therapy. Trans Biomed. 2016;7:e41.

Ready to submit your research? Choose BMC and benefit from

- fast, convenient online submission

- thorough peer review by experienced researchers in your field

- rapid publication on acceptance

- support for research data, including large and complex data types

- gold Open Access which fosters wider collaboration and increased citations

- maximum visibility for your research: over $100 \mathrm{M}$ website views per year

At BMC, research is always in progress.

Learn more biomedcentral.com/submissions 